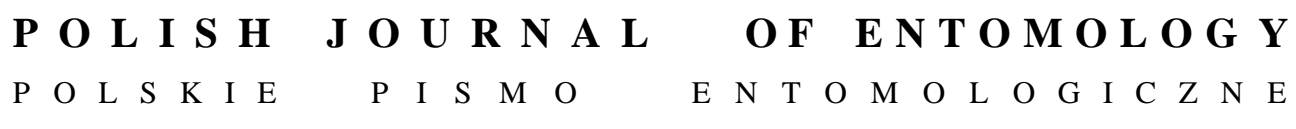

VOL. 86: $251-273$

Lublin

30 September 2017

DOI: $10.1515 /$ pjen-2017-0015

\title{
Unexpected differences in butterfly diversity between two peat bogs in the same area
}

\author{
PRZEMYSŁAW KLIMCZUK* , MARCIN SIELEZNIEW \\ Laboratory of Insect Evolutionary Biology and Ecology, Institute of Biology, \\ University of Bialystok, Ciołkowskiego 1J, 15-245 Białystok, Poland
}

\begin{abstract}
Peat bogs are listed among the most threatened habitats in central Europe, a situation that is reflected by, for example, the conservational status of stenotopic butterflies. Even so, this group remains relatively little studied and most of the available data are limited to qualitative records. The present study enabled us to gain insight into the butterfly fauna of the two largest peat bogs in the Knyszyn Forest (NE Poland), i.e. Bagno Moskal and the one in the Jesionowe Góry nature reserve. The sites, only ca $10 \mathrm{~km}$ apart, are characterized by similar vegetation (mainly the Ledo-Sphagnetum association). The study was carried out in 2013-2015 using the transect method, i.e. regular counts along fixed routes. A total of 37 species, including three tyrphobionts (Colias palaeno, Plebejus optilete and Boloria eunomia) and two tyrphophiles (Callophrys rubi and Boloria euphrosyne), were recorded. The greatest and unexpected differences between the sites were related to the complete absence of $P$. optilete at Bagno Moskal, the significantly higher abundance of B. eunomia at Jesionowe Góry and the greater abundance of B. euphrosyne at Bagno Moskal. In addition, $C$. palaeno was observed sporadically and only at Bagno Moskal. There was some heterogeneity in the distribution and density of particular species, however. Ledum palustre was found to be the most important nectar plant, its flowers also being frequently visited by tyrphoneutrals. The present study shows that isolated island-like habitats (e.g. peat bogs) may possess specific features and be subject to specific independent changes. The results provide a good basis for further research into the habitat preferences of tyrphophilous and tyrphobiontic butterflies, which is important in the context of their conservation.
\end{abstract}

KEY WORDS: Boloria eunomia, Boloria euphrosyne, Callophrys rubi, Colias palaeno, Plebejus optilete, Knyszyn Forest, peat bogs, transect walks, tyrphobionts, tyrphophiles.

\footnotetext{
* Corresponding author: bio_przemek@ poczta.onet.pl
} 


\section{INTRODUCTION}

In this era of climate change and high levels of anthropogenic pressure, raised bogs, mires and boggy pine forests are among the most seriously threatened biotopes. Land reclamation schemes, agriculture, afforestation and peat digging have fragmented them, thereby significantly reducing their coverage (VAN SWAAY \& WARREN 1999, VASANDER et al. 2003). Simultaneous falls in the water table have made them susceptible to successional changes (CZEREPKO 2008, 2011). Peat bogs are characterized by a unique fauna and flora, and although there is little variety in the taxa recorded, they contribute significantly to global biodiversity (MINAYEVA 2008). The species composition of these biotopes differs according to latitude and altitude. Good examples of this variation are butterflies, among which there are some bog specialists (SPITZER \& DANKS 2006, SwEngel \& SwENGEL 2011, UUSITALO et al. 2012, JAROŠ et al. 2014). Moreover, there are local differentiations concerning less specialized species, which often result from human activities (LENSU et al. 2011, NOREIKA et al. 2016).

In Europe, nine butterfly species can be considered specialists of raised bog habitats. Four of them - Colias palaeno (LinNaEus, 1761), Plebejus optilete KNOCH, 1781, Boloria eunomia ESPER, 1799 ('bog ecotype') and B. aquilonaris (STICHEL, 1908) - are relatively widely distributed (boreo-montane species), while Pyrgus centaureae (RAMBUR, 1839), Boloria frigga (THUNBERG, 1791), B. freija (THUNBERG, 1791), Oeneis jutta (HÜBNER, 1806) and Erebia embla (THUNBERG, 1791) are restricted to northern regions (MIKKOLA \& SPITZER 1983, KUdRna 2011). In Finland Coenonympha tullia (MÜLLER, 1764) is also classified as a bog specialist (LENSU et al. 2011, UUSITALO et al. 2012, NOREIKA et al. 2016), although elsewhere it inhabits mainly fens (VAN SWAAY \& WARREN 1999).

Raised bogs are listed among the most vulnerable habitats of European butterflies (VAN SWAAY \& WARREN 1999), especially in Central Europe, where they are scattered and cover smaller areas than in the northern part of the continent. However, even in the latter region attention has been drawn to the decline of bogs caused by drainage and afforestation (VASANDER 2003, UUSITALO et al. 2012, NOREIKA et al. 2016).

The regional conservation status of peatlands is reflected by the local status of specialists related to these kinds of habitats. However, at the European scale (or EU) they are classified as being of 'least concern' (VAN SWAAY et al. 2010) because their habitats are still widespread in Fennoscandia. The situation is quite different in central Europe, where they are usually more or less isolated and therefore much more endangered. In Poland, for instance, all the specialists inhabiting raised bogs are assessed as EN ( $C$. palaeno, P. optilete, B. eunomia and $O$. jutta) or VU (B. aquilonaris). Despite their priority status they are relatively little known. To date, only B. aquilonaris (OLEKSA 2003) and $O$. jutta (KRZYSZTOFIAK et al. 2009) have been the subjects of more detailed studies. Overall, 
however, species associated with peat bogs have tended to be neglected. Recent activities concerning butterflies have been focused on Habitats Directive species, and in Central Europe none of those butterflies inhabits peat bog biotopes.

In the present study we obtained insight into the butterfly fauna of the peat bogs in the Knyszyn Forest, a large complex of woodlands in NE Poland, protected within the Natura 2000 network and recognized as one of the Prime Butterfly Areas in Poland (BUSZKo 2003). A total of 101 species, i.e. around $2 / 3$ of all Polish butterflies, have been recorded there (KLIMCZuK \& Twerd 2000, KLIMCZuK 2011, SIELEZNIEW 2015, SIELEZNIEW $\&$ NOWICKI 2017). This diversity results mainly from the variety of available biotopes. Patches of raised bogs and boggy pine forests are usually small and isolated, however. Previous studies of butterflies carried out in the Knyszyn Forest focused mainly on obtaining data on species distributions and included explorations of the two largest raised bogs (KLIMCZUK 2011 and unpublished). Since certain differences in their butterfly communities were recorded, it was decided to continue and expand this research. The aim of the present paper was to compare the species richness, abundance, phenology and food preferences of butterflies at both sites.

\section{STUDY AREA}

The research was carried out at the Bagno Moskal peat bog (BM) and at the peat bog in the Jesionowe Góry nature reserve (JG). Covering respective areas of about 70 and 50 ha, these two sites, ca $10 \mathrm{~km}$ apart, are situated in the north-western part of the Knyszyn Forest (Fig. 1). The BM site $\left(53^{\circ} 17^{\prime} 35^{\prime}\right.$ 'N $23^{\circ} 09^{\prime} 04^{\prime \prime} \mathrm{E}$; altitude ca $150 \mathrm{~m}$ ) lies to the north of the village of Rybniki and JG $\left(53^{\circ} 19^{\prime} 45^{\prime \prime} \mathrm{N} 23^{\circ} 18^{\prime} 06^{\prime \prime} \mathrm{E}\right.$; alt. ca $\left.155 \mathrm{~m}\right)$ is situated in the immediate vicinity of the village of Machnacz.

The two peat bogs were similar with regard to vegetation. There was no central open bog area at either site, and the majority of this area was occupied by the Ledo-Sphagnetum association. The peat bogs were rather unevenly covered by scrubby Pinus sylvestris L. trees (mostly ca $5 \mathrm{~m}$ in height) and in some places Betula pubescens EHRH. was also present. The characteristic plants of the herb layer were Eriophorum vaginatum L., Ledum palustre L., Vaccinium uliginosum L., V. myrtillus L. (more frequent at BM), Oxycoccus palustris L., Andromeda polifolia L. and Calluna vulgaris (L.) Hull. Apart from the common Sphagnum spp., the mosses included Bryopsida and Polytrichum strictum BRID. 


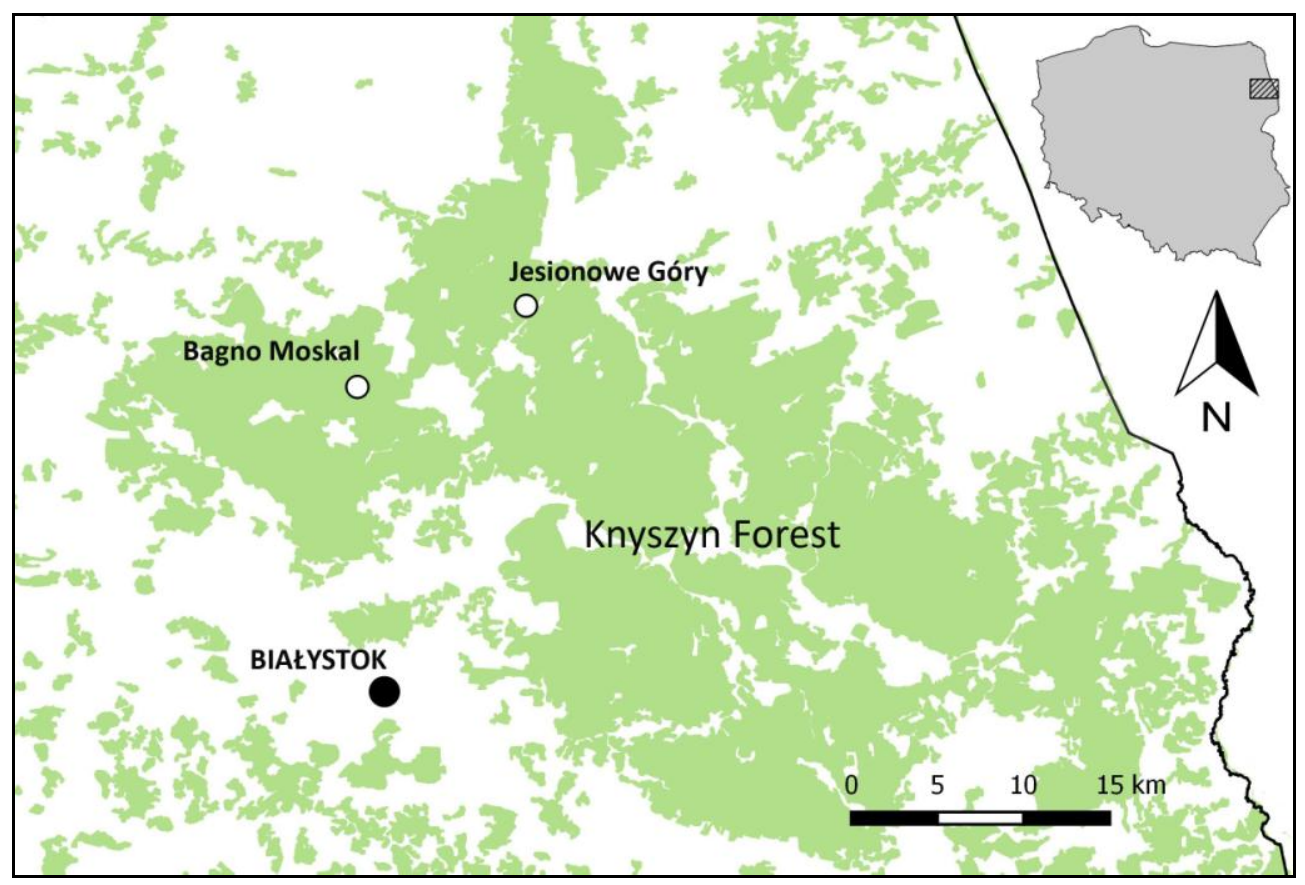

Fig. 1. Location of the study sites in the Knyszyn Forest, NE Poland.

The surroundings of BM consisted mainly of tall coniferous and mixed forests. Open spaces were limited to small clear-felled areas and glades, compartment lines and forest roads. The nearest larger open area lay some $1.5 \mathrm{~km}$ distant. The JG site was surrounded primarily by mixed and deciduous woodland, and unlike BM, was situated very close to an extensive open area including wastelands, fields, meadows, roads and a power line. Moreover, a railway line passes through the area ca $300 \mathrm{~m}$ from the site.

\section{MATERIALS AND METHODS}

The research was carried out in three seasons from 2013 to 2015. The transect method, i.e. butterfly counts along fixed routes (POLLARD \& YATES 1993) with some modifications, was mainly applied. Data and experience concerning the local occurrence of typical peatbog butterflies from previous studies (KLIMCZUK 2011 and unpublished) were used to fix the transects. The total length of the transects was $1880 \mathrm{~m}$ at BM and $1195 \mathrm{~m}$ at JG. Moreover, in 2014-2015 the transects were divided into shorter sections (70-190 m, about 

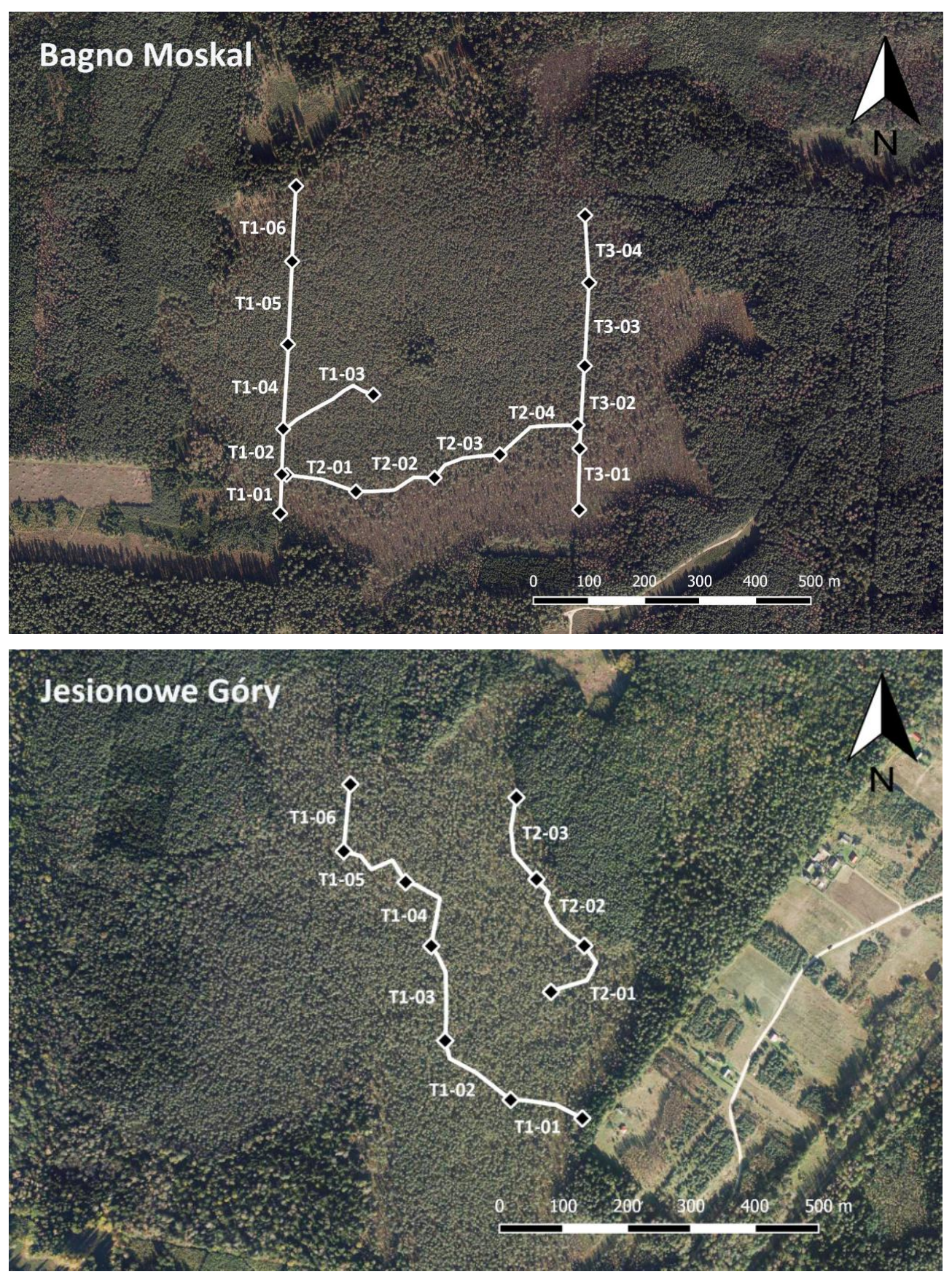

Fig. 2. Orthophotomaps of the study sites with the fixed transect routes divided into sections. 
$135 \mathrm{~m}$ on average) in order to obtain more information on the local distribution of butterflies (Fig. 2). The lengths of each section and of the entire transects were measured accurate to five metres. Butterflies were counted on each section separately.

At least one count was carried out per 10 days, under strict time (between 10:00 and 16:00 hrs CEST) and weather criteria, i.e. on sunny days with a minimum temperature of $15^{\circ} \mathrm{C}$ and weak to moderate wind. To prevent bias, counts were interrupted whenever the weather conditions became adverse (too windy and/or clouds obscured the sun) and were restarted when the criteria were met. The survey focused on observations of butterfly species typical of peat bogs; hence the study season lasted from late April to late July.

The species recorded were classified as tyrphobionts (i.e. species whose life cycle takes place exclusively in peat bogs), tyrphophiles (species whose life cycle can take place either in or beyond peat bogs) or tyrphoneutrals (species whose life cycle takes place only outside peat bogs) according to DANKS \& SPITZER (2006).

An index of abundance was calculated for each species for particular transects/sections. The index was the sum of counts made in each 10-day period of a month. Only a few counts were missed - these gaps were filled by means calculated from the preceding and succeeding counts. All abundance indices were converted per 100 metres to allow comparisons between species, transects and sections.

Annual abundance indices were used to compare butterfly communities between sites by calculating the percentage of particular butterfly species in the pooled abundance index of all species in each year (Table 1).

The Shannon-Wiener biodiversity index was also calculated for each site and season according to the equation below:

$\mathrm{H}^{\prime}$ - Shannon-Wiener index of biodiversity

$$
\mathrm{H}^{\prime}=-\Sigma\left(\mathrm{p}_{i} \ln \mathrm{p}_{i}^{2}\right)
$$

$\mathrm{p}_{i}$ - proportion of individuals belonging to the $i$ th species in the total sample

Besides the transect counts, additional observations of butterflies were made along variable routes in order to obtain complete species lists for the study sites. Qualitative and quantitative surveys yielded data on the food preferences of imagoes. Because of the small overall number of records of feeding individuals, all such data obtained in 2013-2015 were pooled for each site.

Some observations of ovipositing females were also made. Additionally, in late April 2014 we searched for Boloria MOORE, 1900 caterpillars at the JG site. 


\begin{tabular}{|c|c|c|c|c|c|c|c|c|c|c|c|c|c|c|c|c|c|c|c|c|}
\hline & $=$ & & & & 总 & : & & & 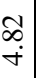 & $\propto$ & & & & 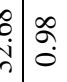 & 6 & & 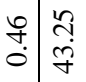 & & & \\
\hline & 童苛 & 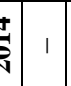 & 1 & 1 & 1 & 1 & & & $\stackrel{m}{\dot{\sigma}}$ & ๙ & & 1 & 1 ले & $\hat{n}$ & $\begin{array}{c}\stackrel{c}{1} \\
\infty\end{array}$ & $\begin{array}{l}\overrightarrow{0} \\
\dot{0}\end{array}$ & $\begin{array}{l}1 \\
1 \\
\dot{b} \\
\dot{q}\end{array}$ & & I & \\
\hline & 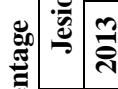 & 9 & 1 & 1 & ڤ્o & 1 & & & - & 1 lo & & 1 & \begin{tabular}{l|l|l} 
& $\vec{G}$ \\
\end{tabular} & $\begin{array}{ll}0 \\
0\end{array}$ & $\begin{array}{l}\tilde{n} \\
\tilde{r}\end{array}$ & & 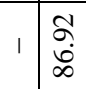 & & । & \\
\hline & 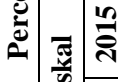 & 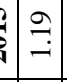 & $\stackrel{9}{=}$ & 色 & 1 & 1 & & & $\begin{array}{l}1 \\
\infty \\
\dot{+} \\
\end{array}$ & 10 & & 1 & $1 \mid \begin{array}{l}\bar{ल} \\
\widehat{d}\end{array}$ & & & & 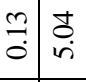 & 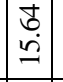 & । & \\
\hline & 竞 & 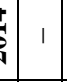 & $\begin{array}{l}0 \\
b \\
i \\
\end{array}$ & 1 & 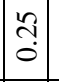 & 1 & & $\begin{array}{lll}9 & 0 \\
\vdots & 0 & 0 \\
0\end{array}$ & î & $\begin{array}{c}t \\
b \\
b\end{array}$ & & 1 & & $\begin{array}{l}0 \\
\dot{f} \\
0\end{array}$ & I & 1 & 1 ठู & $\mid \begin{array}{l}\mathcal{y} \\
\stackrel{2}{2}\end{array}$ & । & \\
\hline & $\stackrel{\sim}{\square}$ & । & 年 & 1 & 1 & 1 & 1 & & 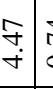 & $\begin{array}{lll}5 \\
0\end{array}$ & & 1 & $1 \frac{7}{\sim}$ & 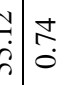 & & & 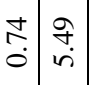 & & 1 & $\cong$ \\
\hline & : & $\begin{array}{l}a \\
\vdots \\
\vdots\end{array}$ & 1 & & $\begin{array}{l}\infty \\
0 \\
0 \\
0\end{array}$ & 童 & & & $\begin{array}{l} \pm \\
\vdots \\
0\end{array}$ & $1 \mid \begin{array}{l}d \\
a \\
c\end{array}$ & & 1 & & $\begin{array}{l}0 \\
\\
0\end{array}$ & $\bar{n}$ & & 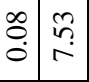 & - & - & \\
\hline & 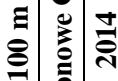 & - & & 1 & & 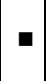 & & & $\begin{array}{l}0 \\
\vdots \\
0\end{array}$ & & & 1 & & ç: & $\stackrel{\vec{n}}{-}$ & $\frac{m}{0}$ & $\underset{\infty}{\vec{\sigma}}$ & - & 1 & \\
\hline & 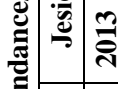 & 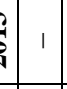 & - & & \begin{tabular}{|l|}
$\infty$ \\
0 \\
0 \\
\end{tabular} & - & - & & $\begin{array}{l}0 \\
\vdots \\
0 \\
0\end{array}$ & & & 1 & & \begin{tabular}{l|l}
0 \\
\hdashline & 1 \\
& 1
\end{tabular} & $\tilde{\sigma}$ & & \begin{tabular}{l|l}
1 & $\mathbb{N}$ \\
$\dot{d}$ \\
$\mathbb{d}$
\end{tabular} \mid & 1 & 1 & \\
\hline & త్ & â. & \begin{tabular}{|l}
$\hat{y}$ \\
0 \\
\end{tabular} & $\left|\begin{array}{l}\infty \\
0 \\
0\end{array}\right|$ & - & - & & & ô. & 1 l 18 & 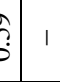 & 1 & 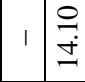 & 管 & 1 & & 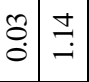 & $\mid \begin{array}{l}n \\
m \\
m \\
m\end{array}$ & 1 & \\
\hline & 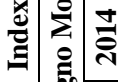 & - & & 1 & 年 & & & $\begin{array}{lll}\infty & \\
0 \\
0\end{array}$ & 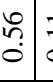 & $\overrightarrow{0}: \frac{9}{c}$ & 6 & 1 & 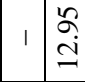 & 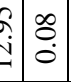 & & - & $1)$ & $\mid \begin{array}{l}\vec{i} \\
\mathrm{i}\end{array}$ & I & . \\
\hline & 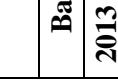 & 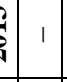 & : & I & 1 & 1 & & & 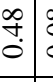 & 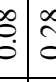 & & - & $-\begin{array}{l}\sigma \\
\dot{\gamma} \\
\dot{\gamma}\end{array}$ & $\begin{array}{c}y \\
\end{array}$ & & $\begin{array}{ll}\infty \\
0 \\
0 \\
0\end{array}$ & 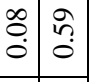 & $\overrightarrow{\vec{i}}$ & & $\stackrel{7}{0}$ \\
\hline . & कूँ & 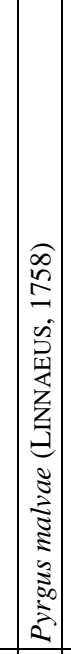 & 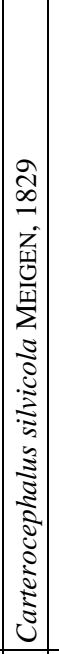 & 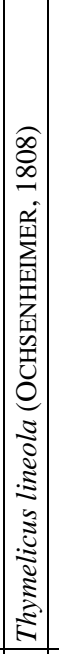 & 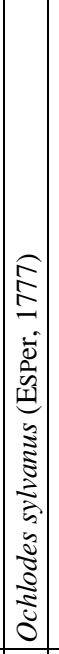 & 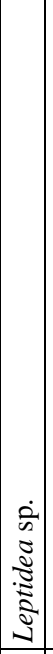 & 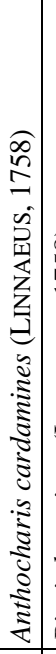 & 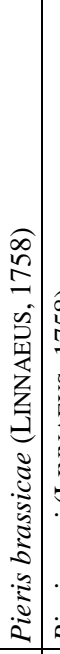 & 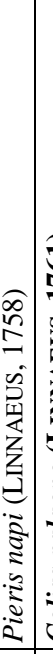 & 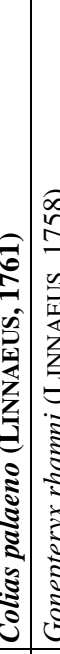 & 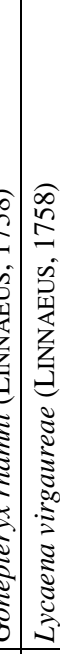 & 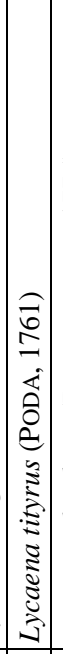 & 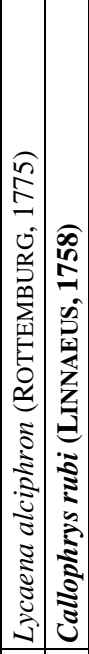 & 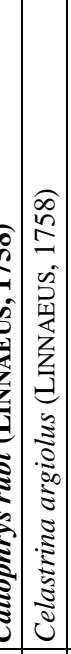 & 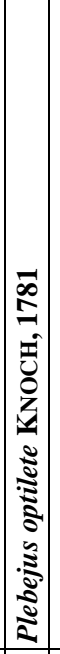 & 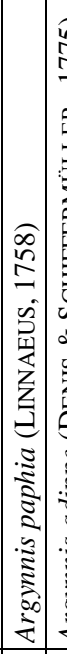 & 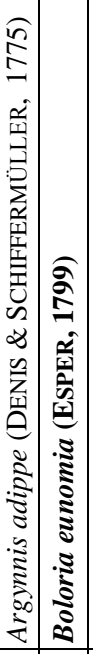 & 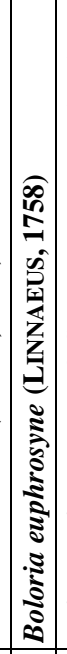 & 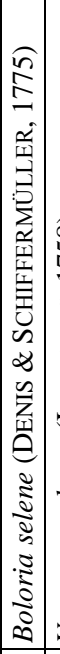 & 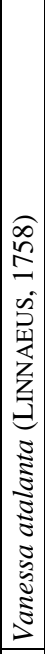 \\
\hline & & $-i$ & $|\mathrm{i}|$ & $|\dot{ }|$ & $\dot{+}$ & in & & $\therefore \circ$ & $\infty \mid$ & $\sigma^{\circ}=$ & $\dot{\vec{a}}=\dot{\vec{z}}$ & i & $\stackrel{\dot{I}}{\dot{2}}$ & $\dot{\dot{0}}$ & $\stackrel{\dot{\theta}}{ }$ & 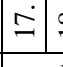 & $\stackrel{\infty}{-}$ & |ิं & $|\dot{\vec{\lambda}}|$ & \\
\hline & & & & & & & & & & & & & & & & & & & & \\
\hline
\end{tabular}




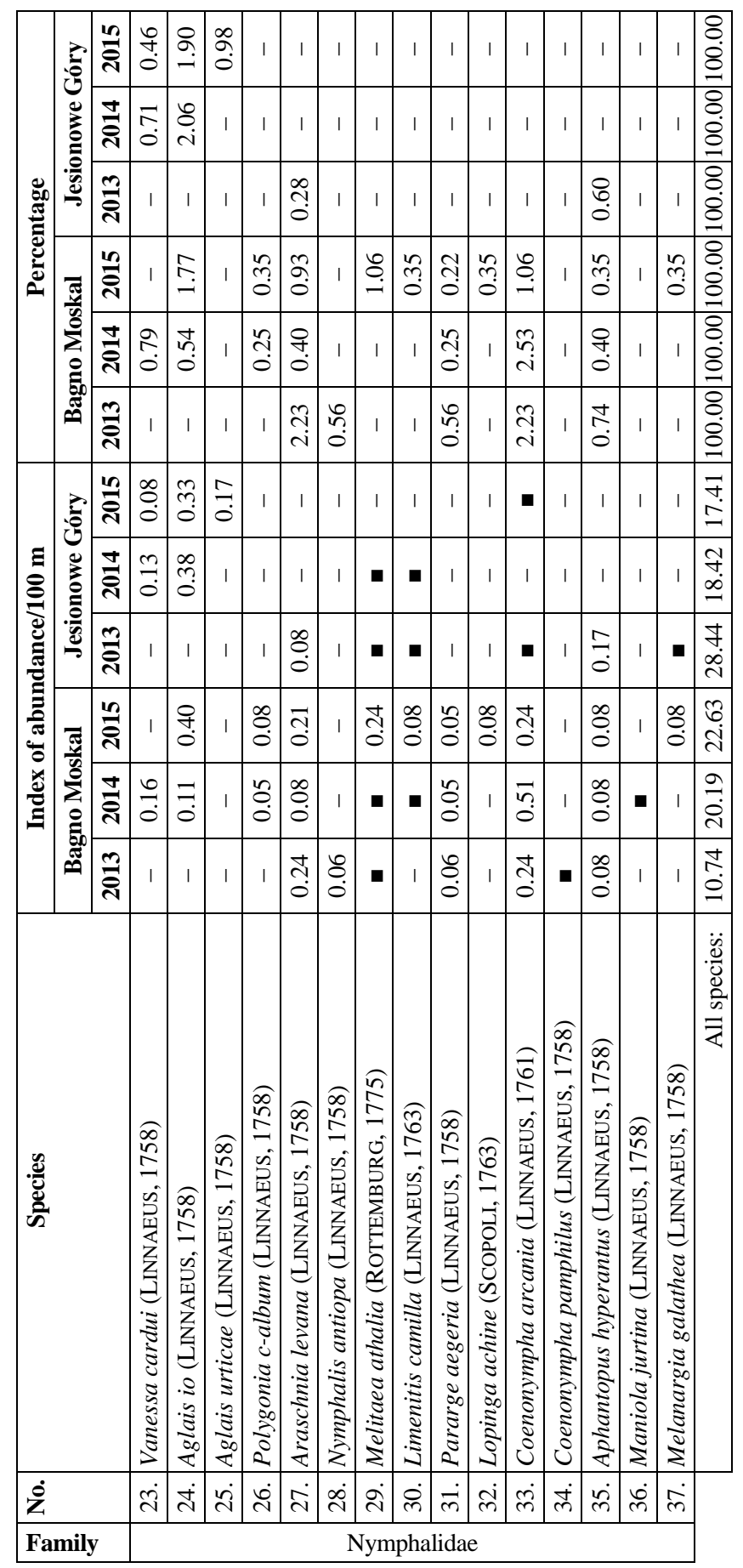




\section{RESULTS}

\section{Species richness}

A total of 37 species were detected during observations at BM and JG in 2013-2015. Species richness was higher at BM, where 33 species were recorded, including 27 species along the fixed transects. The respective figures for JG are 26 and 16 species. Thirty species were found along the transects on both sites. There were conspicuous differences in the numbers of species between the two raised bogs in each season (Table 1). However, only twelve species at BM and six at JG were consistently recorded every year (ten and five on the transects, respectively).

From one to ten butterfly species at BM and from two to seven at JG were observed on individual transect sections. At BM, the species richness was the highest in the western part of the site along the wide forest compartment line, and the lowest on some sections in the south and east. In contrast, the sections at JG were more homogeneous in terms of species richness, and the highest number of species was observed in the central part of the site.

Altogether, three tyrphobionts (Colias palaeno, Plebejus optilete and Boloria eunomia) and two tyrphophiles (Callophrys rubi and Boloria euphrosyne) were recorded. However, only $C$. rubi and B. eunomia turned out to be permanent residents at both sites. $B$. euphrosyne, regularly counted at BM, was noted at JG only in 2014 and 2015. In contrast, $P$. optilete, observed every year at JG, was never found at BM. Finally, C. palaeno was recorded exclusively at BM in 2013 and 2014.

The species regularly sighted included some not related to raised bogs (tyrphoneutrals). Two common ubiquitous species Pieris napi and Gonepteryx rhamni were recorded at both sites, while at BM six others (Carterocephalus silvicola (MEIGEN, 1829), Celastrina argiolus (LINNAEUS, 1758), Araschnia levana (LINNAEUS, 1758), Pararge aegeria (LINNAEUS, 1758), Coenonympha arcania (LINNAEUs, 1761) and Aphantopus hyperantus (LINNAEUS, 1758)) were encountered every year. Table 1 lists all the species recorded.

\section{Relative abundance}

From 2013 to 2015 a total of 857 and 686 butterflies were counted along the fixed transects at BM and JG respectively. There were differences in the proportions of the species recorded most often between sites and seasons (Fig. 3). The species most frequently counted at BM were C. rubi and B. euphrosyne (517 and 157 respectively), while the most common one at JG was B. eunomia (443). At the former site the percentage of the most frequently counted species was very similar in all the study seasons - this was reflected in the similar Shannon-Wiener diversity indices (1.47 in 2013, 1.37 in 2014, and 1.40 in 2015). At JG the proportions of the particular species were similar to each other only in 2014 and 2015, so the $H^{\prime}$ values did not differ too much either (1.29 and 1.50, 
respectively). However, season 2013 was exceptional at this site owing to the relatively high abundance of B. eunomia, which contributed to the lowest value of $\mathrm{H}^{\prime}(0.56)$.

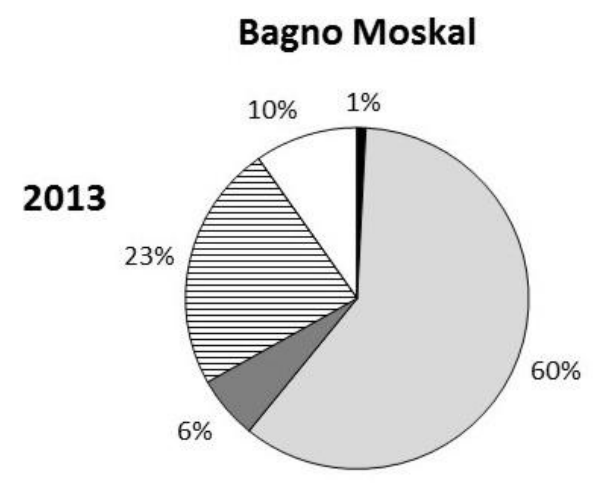

\section{Jesionowe Góry}
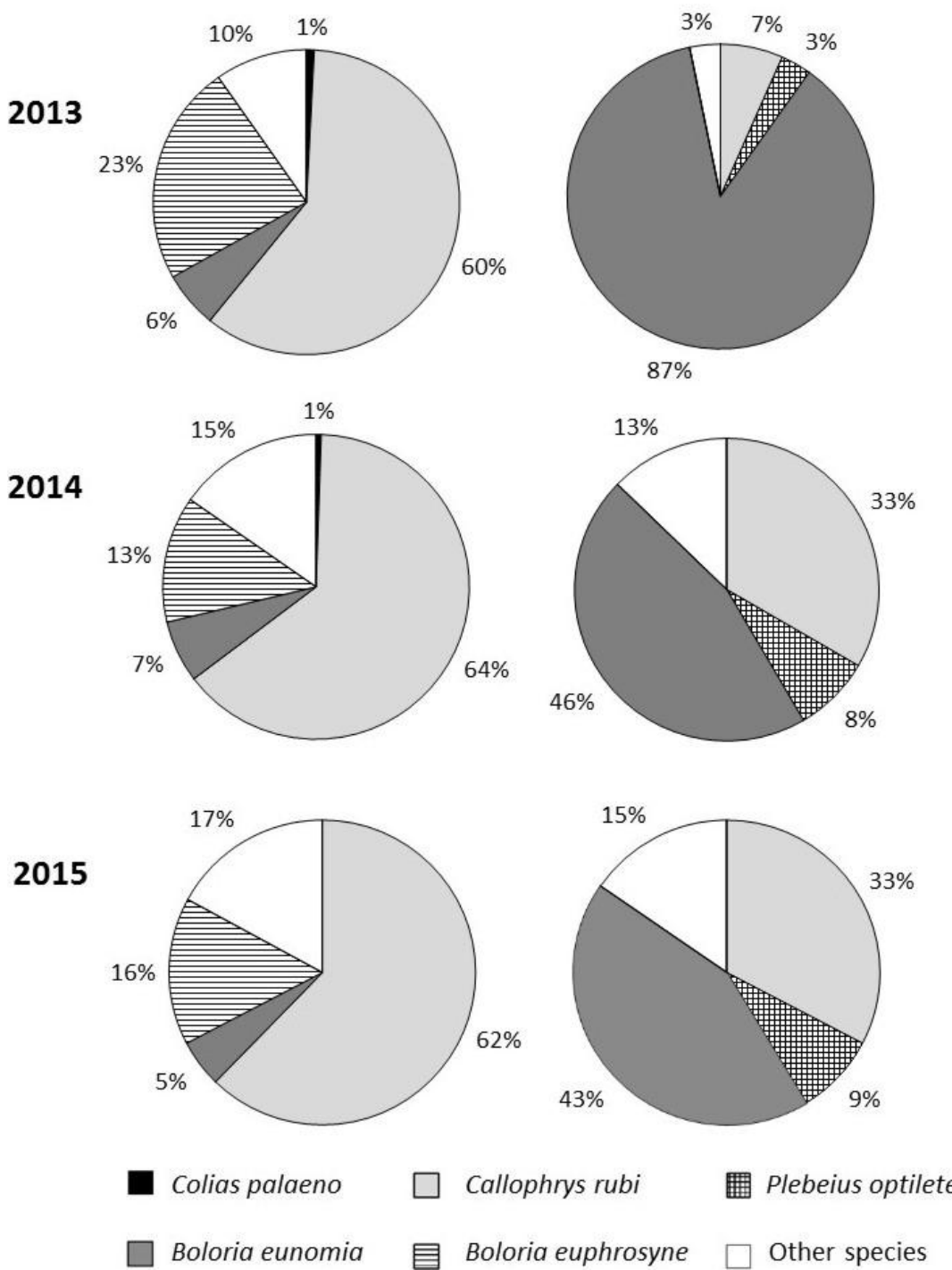

Fig. 3. Percentages of tyrphobionts and tyrphophiles in the butterfly fauna at the study sites in 2013-2015. 
Boloria eunomia was observed on all transect sections at JG, the highest abundance indices being recorded along central sections that crossed patches with a minimal tree cover and a high proportion of Ericaceae shrubs (mainly Ledum palustre). In contrast, the lowest abundance of this butterfly was recorded close to the north-western edges of the bog on densely wooded patches.

However, at BM the relative abundance of B. eunomia was significantly lower in each year compared to JG (six times in 2014-15 and as many as 40 times in 2013). The species was the most numerous in the western sections of transects rich in Ericaceae plants. Moreover, this part of the bog was crossed by a forest compartment line (about $5 \mathrm{~m}$ wide), which meant a significantly thinner canopy of Pinus sylvestris. In contrast to JG, $B$. eunomia at BM was not recorded on some sections at all, especially in patches with a dense tree cover, very low shrubs and/or close to the margins of the bog dominated by Vaccinium myrtillus. The maximum abundance index of B. eunomia per section at BM (6.47) was lower than the average abundance index calculated for the whole transect at JG (7.5324.72) in each season.

Another major difference between the two sites concerned B. euphrosyne. At JG the species was rare, i.e. only single individuals were sighted, but they were not recorded during transect counts. However, at BM B. euphrosyne was counted on all sections and was, moreover, much more numerous than B. eunomia (annual abundance indices were 2-4 times higher).

Callophrys rubi was the butterfly most often counted at BM, its annual indices being 2-3 times higher than at JG. It was recorded on all sections of the transects at both sites, but at JG its distribution was much more even. At BM it turned out to be the most abundant in the southern part of the bog in patches with P. sylvestris and Betula spp. in the tree stand and a dense coverage of Vaccinium uliginosum and V. myrtillus. It was also frequently recorded along the well-insolated compartment line on the western part of the transect as well as at the northern edges of the bog rich in $V$. myrtillus. The smallest numbers of individuals were recorded in patches with a dense tree cover and a small proportion of Ericaceae shrubs. At both sites C. rubi was the least numerous in 2013.

Another lycaenid, $P$. optilete, recorded exclusively at JG, was the third most frequently counted species at this site in all the study seasons. This butterfly was the most common in well-insolated patches with large aggregations of $V$. uliginosum shrubs in the north-central part of the bog. It was completely absent from some sections, however. Colias palaeno was recorded only at BM in 2013 and 2014. Just one and two individuals respectively were counted on the fixed transects in the W and SW parts of the bog along the compartment line. During additional observations another five and two individuals were observed in these two years respectively. 
Table 2. Abundance indices of tyrphobionts and tyrphophiles and the numbers of all butterfly species recorded on particular sections of transects at Bagno Moskal in 20142015. The numbers of tyrphobionts and tyrphophiles are given in parenthesis.

\begin{tabular}{|c|c|c|c|c|c|c|c|c|c|c|}
\hline \multirow{2}{*}{ Section } & \multicolumn{9}{|c|}{ Abundance index per 100 m } & \multicolumn{2}{c|}{$\begin{array}{c}\text { Number of } \\
\end{array}$} & $\begin{array}{c}\text { Colias } \\
\text { palaeno }\end{array}$ & $\begin{array}{c}\text { Callophrys } \\
\text { rubi }\end{array}$ & $\begin{array}{c}\text { Boloria } \\
\text { eunomia }\end{array}$ & \multicolumn{2}{c|}{$\begin{array}{c}\text { Boloria } \\
\text { euphrosyne }\end{array}$} & \multicolumn{2}{c|}{ species } \\
\cline { 2 - 11 } & $\mathbf{2 0 1 4}$ & $\mathbf{2 0 1 5}$ & $\mathbf{2 0 1 4}$ & $\mathbf{2 0 1 5}$ & $\mathbf{2 0 1 4}$ & $\mathbf{2 0 1 5}$ & $\mathbf{2 0 1 4}$ & $\mathbf{2 0 1 5}$ & $\mathbf{2 0 1 4}$ & $\mathbf{2 0 1 5}$ \\
\hline T1-01 & 1.43 & 0.00 & 24.29 & 22.86 & 1.43 & 0.00 & 1.43 & 2.14 & $7(4)$ & $7(2)$ \\
\hline T1-02 & 1.18 & 0.00 & 21.76 & 24.71 & 2.35 & 6.47 & 5.88 & 5.88 & $6(4)$ & $6(3)$ \\
\hline T1-03 & 0.00 & 0.00 & 2.11 & 3.68 & 0.53 & 2.11 & 5.26 & 1.05 & $4(3)$ & $6(3)$ \\
\hline T1-04 & 0.00 & 0.00 & 17.00 & 14.33 & 6.00 & 3.67 & 3.33 & 9.00 & $7(3)$ & $10(3)$ \\
\hline T1-05 & 0.00 & 0.00 & 4.33 & 6.00 & 2.00 & 0.33 & 1.33 & 0.67 & $6(3)$ & $6(3)$ \\
\hline T1-06 & 0.00 & 0.00 & 15.56 & 14.81 & 0.00 & 0.74 & 3.70 & 1.85 & $5(2)$ & $8(3)$ \\
\hline T2-01 & 0.00 & 0.00 & 15.38 & 20.77 & 1.54 & 0.77 & 1.54 & 3.85 & $5(3)$ & $5(3)$ \\
\hline T2-02 & 0.00 & 0.00 & 28.33 & 31.00 & 0.00 & 0.00 & 2.00 & 2.00 & $3(2)$ & $3(2)$ \\
\hline T2-03 & 0.00 & 0.00 & 22.31 & 26.15 & 0.00 & 0.00 & 2.31 & 5.38 & $4(2)$ & $3(2)$ \\
\hline T2-04 & 0.00 & 0.00 & 14.69 & 11.25 & 3.75 & 0.63 & 3.75 & 3.75 & $5(3)$ & $4(3)$ \\
\hline T3-01 & 0.00 & 0.00 & 5.91 & 9.55 & 0.00 & 0.00 & 1.82 & 3.64 & $4(2)$ & $4(2)$ \\
\hline T3-02 & 0.00 & 0.00 & 2.00 & 4.00 & 0.00 & 0.00 & 0.00 & 3.33 & $1(1)$ & $4(2)$ \\
\hline T3-03 & 0.00 & 0.00 & 7.33 & 8.00 & 0.67 & 2.00 & 4.00 & 4.67 & $5(3)$ & $5(3)$ \\
\hline T3-04 & 0.00 & 0.00 & 12.92 & 14.58 & 0.00 & 0.00 & 0.83 & 3.33 & $4(2)$ & $6(2)$ \\
\hline Mean & 0.19 & 0.00 & 13.85 & 15.12 & 1.31 & 1.19 & 2.66 & 3.61 & $4.7(2.6)$ & $5.5(2.6)$ \\
\hline
\end{tabular}

Table 3. Abundance indices of tyrphobionts and tyrphophiles and the numbers of all butterfly species recorded on particular sections of transects at Jesionowe Góry in 20142015. The numbers of tyrphobionts and tyrphophiles are given in parenthesis.

\begin{tabular}{|c|c|c|c|c|c|c|c|c|}
\hline \multirow{2}{*}{ Section } & \multicolumn{9}{|c|}{ Abundance index per 100 m } & \multicolumn{2}{c|}{ Number of species } \\
\cline { 2 - 9 } & \multicolumn{2}{|c|}{ Callophrys rubi } & \multicolumn{2}{|c|}{ Plebejus optilete } & \multicolumn{2}{|c|}{ Boloria eunomia } & \multicolumn{2}{|c|}{} \\
\cline { 2 - 9 } & $\mathbf{2 0 1 4}$ & $\mathbf{2 0 1 5}$ & $\mathbf{2 0 1 4}$ & $\mathbf{2 0 1 5}$ & $\mathbf{2 0 1 4}$ & $\mathbf{2 0 1 5}$ & $\mathbf{2 0 1 4}$ & $\mathbf{2 0 1 5}$ \\
\hline T1-01 & 2.50 & 0.83 & 0.00 & 0.00 & 6.67 & 7.50 & $2(2)$ & $3(2)$ \\
\hline T1-02 & 7.59 & 8.97 & 1.72 & 4.14 & 13.79 & 13.79 & $5(3)$ & $6(3)$ \\
\hline T1-03 & 7.42 & 4.52 & 1.94 & 0.65 & 4.19 & 9.03 & $4(3)$ & $6(3)$ \\
\hline T1-04 & 11.48 & 2.96 & 1.11 & 0.74 & 11.85 & 4.44 & $6(3)$ & $6(3)$ \\
\hline T1-05 & 5.38 & 8.46 & 4.62 & 5.38 & 13.85 & 8.46 & $7(3)$ & $7(3)$ \\
\hline T1-06 & 3.81 & 3.81 & 2.86 & 0.95 & 8.57 & 8.57 & $5(3)$ & $7(3)$ \\
\hline T2-01 & 5.60 & 14.40 & 0.00 & 0.80 & 10.40 & 8.80 & $3(2)$ & $5(3)$ \\
\hline T2-02 & 7.04 & 5.19 & 0.00 & 0.74 & 3.70 & 5.19 & $5(2)$ & $6(3)$ \\
\hline T2-03 & 3.45 & 2.07 & 1.03 & 0.00 & 3.45 & 2.07 & $4(3)$ & $4(2)$ \\
\hline Mean & 6.03 & 5.69 & 1.48 & 1.49 & 8.50 & 7.54 & $4.6(2.4)$ & $5.6(2.8)$ \\
\hline
\end{tabular}


Other butterfly species, i.e. tyrphoneutrals were rarely sighted, and their annual indices of abundance were in most of cases less than 1/100 $\mathrm{m}$ (Table 1).

Indices of abundance and percentages of all species for both sites are given in Table 1. Abundance indices of tyrphobionts/tyrphophiles as well as overall species richness for particular transect sections are presented in Tables 2 and 3.

\section{Phenology and seasonal variability}

The study seasons differed as regards weather conditions, which affected the flight period of particular species (Fig. 4). In 2013, the beginning of spring was cold and at the end of April there were still patches of snow at the study sites. The earliest species, i.e. $C$. rubi, did not emerge until early May, its abundance peaking around 20 May at both BM and JG. In contrast, April 2014 was warm and C. rubi emerged earlier and achieved maximum abundance in early May. The flight period of $C$. rubi was relatively long compared to other species and lasted from fifty (2013) to seventy days (2015).

The flight period of B. eunomia was about half as long as that of $C$. rubi in each season and was restricted almost solely to June. Only in $2014 \mathrm{did}$ B. eunomia emerge at the end of May, with numbers peaking in early June. Some differences between the two sites in the particular seasons were discernible: in 2013 the peak of abundance at JG occurred in early June whereas at BM it took place ten days later. This difference was less clear-cut in 2015.

Boloria euphrosyne was recorded during transect counts only at BM, where its abundance peaked in 2013 and 2015 earlier than B. eunomia at that site; in 2014 there was no difference. At JG only three individuals were observed during the three-year study (two on 21 May 2014 and one on 6 June 2015). Only ten specimens of C. palaeno were recorded, all of them at BM. No more than three individuals were encountered on the transects (on 1 July 2013, 31 May 2014 and 13 June 2014). Individuals beyond the transects were noted on the following days: 12 June 2013 (2), 20 June 2013 (1), 1 July 2013 (2) and 13 June 2014 (2). This butterfly has been omitted from the flight period comparison on Fig. 4 because of the practically random observations of single individuals without any discernible trend in the results. The only thing the data suggest is that this species occurred earlier in 2014 than in 2013.

Finally, $P$. optilete was observed only at JG, emerging in each season as the last of the tyrphobionts and tyrphophiles. Its flight period lasted from thirty (2013) to fifty days (2015), with numbers peaking in the second half of June.

It was also observed that the abundance of all five species peaked, to a greater or lesser extent, near the beginning of the flight period (Fig. 4). 


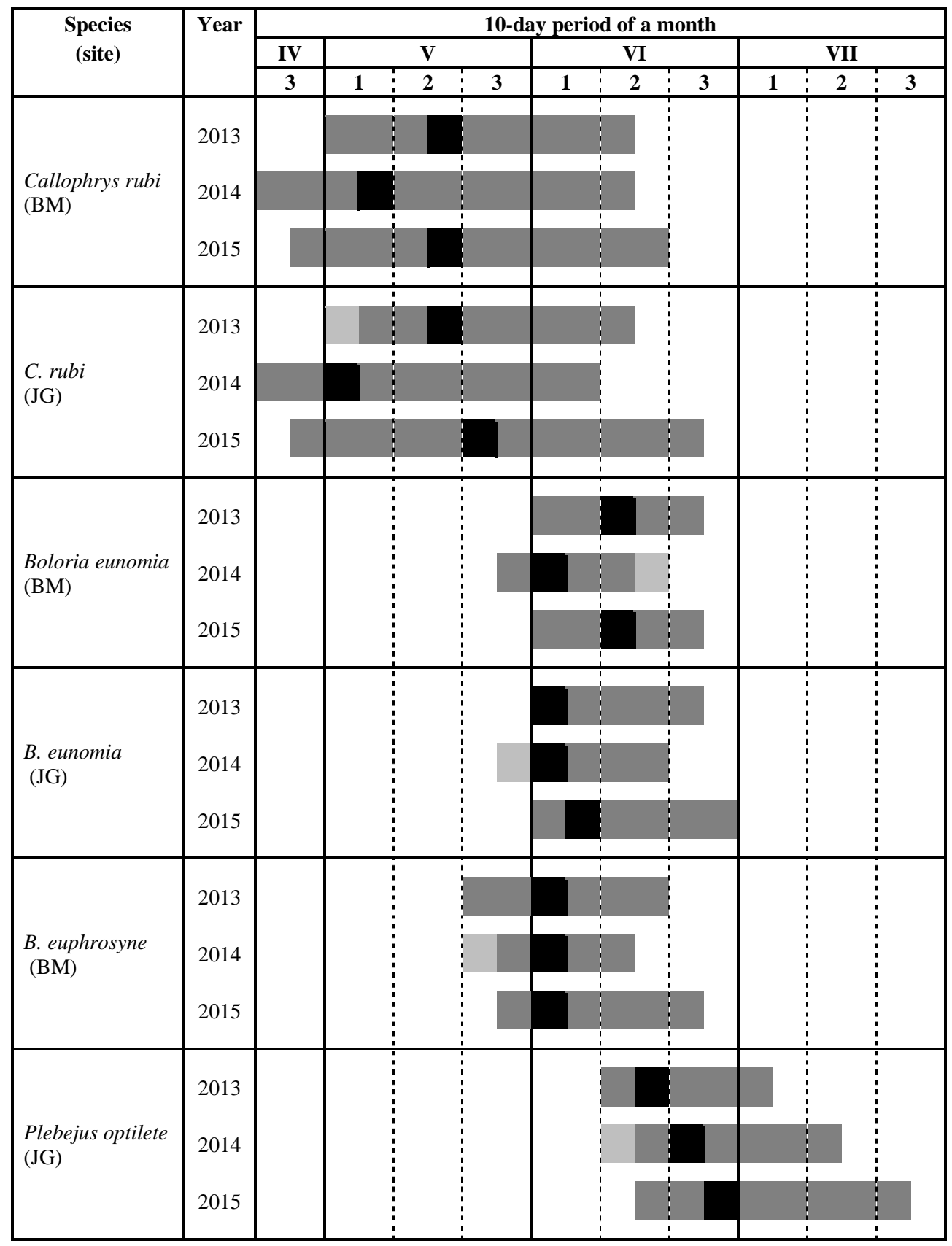

Fig. 4. Phenology of selected species at the two study sites. The flight periods of the butterflies (grey bars) and peaks of abundance (black squares) are shown accurate to 5 days. Possible prolonged flight periods are marked in a paler shade of grey. Months: IV - April, V - May, VI - June, VII - July. 
Table 4. Number of records of butterflies feeding on particular food resources at both sites. Led pal-Ledum palustre, Oxy pal-Oxycoccus palustris, Vac myr-Vaccinium myrtillus, Vac uli - Vaccinium uliginosum, wet gro - wet ground.

\begin{tabular}{|c|c|c|c|c|c|c|c|c|c|c|c|c|}
\hline \multirow[t]{3}{*}{ Butterfly species } & \multicolumn{12}{|c|}{ Site and food source } \\
\hline & \multicolumn{6}{|c|}{ Bagno Moskal } & \multicolumn{6}{|c|}{ Jesionowe Góry } \\
\hline & 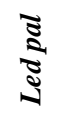 & & $\begin{array}{l}\hat{\Xi} \\
\bar{\Xi} \\
\vdots\end{array}$ & $\begin{array}{l}\tilde{\Xi} \\
\tilde{\Xi} \\
\vdots\end{array}$ & 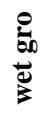 & 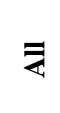 & $\frac{\bar{\Xi}}{\tilde{\Xi}}$ & $\frac{\Xi}{5}$ & $\begin{array}{l}\hat{\Xi} \\
\stackrel{\Xi}{\Xi} \\
\Xi\end{array}$ & 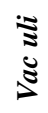 & $\begin{array}{l}0 \\
\dot{0} \\
0 \\
0\end{array}$ & $\bar{z}$ \\
\hline Pyrgus malvae & & & & & 3 & 3 & & & & & & \\
\hline Carterocephalus silvicola & 4 & & & & 5 & 9 & & & & & & \\
\hline Ochlodes sylvanus & 2 & & & & & 2 & 2 & & & & & 2 \\
\hline Leptidea sp. & 1 & & & & & 1 & & & & & & \\
\hline Pieris napi & 1 & & & & 1 & 2 & 2 & & & & & 2 \\
\hline Gonepteryx rhamni & & & & & & & 2 & & & & 1 & 3 \\
\hline Lycaena tityrus & 1 & & & & & 1 & & & & & & \\
\hline Callophrys rubi* & 62 & 1 & 2 & 1 & 10 & 76 & 24 & & & & 1 & 25 \\
\hline Plebejus optilete* $^{*}$ & & & & & & & 1 & & & & & 1 \\
\hline Boloria eunomia* & 15 & 5 & & & & 20 & 122 & 40 & & & 1 & 163 \\
\hline Boloria euphrosyne* & 43 & 2 & & 1 & 1 & 47 & 2 & & & & & 2 \\
\hline Vanessa atalanta & 1 & & & & & 1 & & & & & & \\
\hline Vanessa cardui & 3 & & & & & 3 & 5 & & & & & 5 \\
\hline Aglais urticae & & & & & & & 2 & & & & & 2 \\
\hline Araschnia levana & 3 & & & & 2 & 5 & & & & & & \\
\hline Nymphalis antiopa & & & & & 1 & 1 & & & & & & \\
\hline Melitaea athalia & & & & & & & 1 & & & & & 1 \\
\hline Pararge aegeria & 1 & & & & & 1 & & & & & & \\
\hline *Tyrphobionts/tyrphophiles & 120 & 8 & 2 & 2 & 11 & 143 & 149 & 40 & 0 & 0 & 2 & 191 \\
\hline Other species & 17 & 0 & 0 & 0 & 12 & 29 & 14 & 0 & 0 & 0 & 1 & 15 \\
\hline All species & 137 & 8 & 2 & 2 & 23 & 172 & 163 & 40 & 0 & 0 & 3 & 206 \\
\hline
\end{tabular}

\section{Feeding preferences}

Ninety-nine feeding butterflies (belonging to 14 species) were spotted along the transects at BM, i.e. about $12 \%$ of the total counted. Another 73 feeding individuals were recorded during additional observations. Most of the butterflies visited flowers (87\%), while the others acquired water and probably some nutrients from wet ground $(13 \%)$. Ledum palustre was the most important food resource with respect to both pooled observations (80\%) and the most common species, i.e. C. rubi (82\%), B. euphrosyne (92\%) and B. eunomia (75\%). Then Oxycoccus palustris was visited only by $5 \%$ of feeding 
butterflies, while just single individuals were observed on V. myrtillus and V. uliginosum. Some butterflies took moisture from wet ground: the most frequent of these were $C$. rubi and C. silvicola (Table 4).

At JG, 83 feeding butterflies ( 10 species) were recorded during the transect walks (i.e. about $12 \%$ of the total number counted) and a further 123 were recorded beyond the transects. As at BM, L. palustre turned out to be the main food resource (79\% of all observations). Callophrys rubi fed almost exclusively on that plant (96\%), while the most common B. eunomia nectared not only on L. palustre (75\%) but also on O.palustris (24\%). No other plants were visited and just three butterflies were spotted on wet ground.

Table 4 lists the details concerning feeding.

\section{Larval food plants}

Some random and irregular observations of ovipositing females were also made. Plebejus optilete laid eggs on V. uliginosum (JG), B. eunomia on O. palustris or (close to it) on Sphagnum spp. (JG), C. rubi on V. uliginosum (BM and JG) and V. myrtillus (only BM), $B$. euphrosyne on $O$. palustris, mosses and dry plant fragments on the ground, e.g. pine needles $(\mathrm{BM})$.

Larvae of $B$. eunomia were also noted feeding on $O$. palustris or basking nearby at JG in the spring.

\section{DISCUSSION}

Similar in terms of vegetation and situated only $10 \mathrm{~km}$ apart, the two study sites differed considerably with respect to their butterfly fauna. The higher overall diversity of butterflies observed at BM could be explained by its position - a relatively isolated, semi-open area abundant in nectar sources (mostly flowers of Ledum palustre) and therefore also attractive to tyrphoneutrals. In contrast, the JG peat bog adjoined other sunny biotopes.

The species most commonly recorded at both JG and BM were tyrphobionts and tyrphophiles, but the species composition and relative abundance differed. The most surprising result was the absence of Plebejus optilete at BM despite the presence of potentially suitable habitats. Colias palaeno, which uses the same larval food plant (Vaccinium uliginosum) was observed in 2013-2014 exclusively at BM and then only in very low numbers. The lack of observations in 2015 suggested this butterfly's local extinction but it was recorded again in 2016. Interestingly, single individuals of $C$. palaeno were also recorded at JG but outside the period of the present study (2010 and 2016), which indicates that the species still persists there (KLIMCZUK 2011 and unpublished). 
Similarly, the large differences in abundance of Boloria euphrosyne and B. eunomia between the two raised bogs were unexpected. The former species was relatively abundant only at BM, although its potential larval host plants were numerous at both sites. At JG $B$. euphrosyne was observed in low numbers and only in seasons 2014 and 2015. Since it was not recorded at that site during previous studies (KLIMCZUK 2011 and unpublished), it is hard to predict any trend regarding its future occurrence there. Conversely, B. eunomia was the dominant species at JG, whereas at BM it was relatively rare. Differences in the abundance of $B$. eunomia and $B$. euphrosyne may be due to unknown microhabitat preferences of both species and subtle habitat differences.

Callophrys rubi, recorded in high numbers both at BM and JG, finds suitable conditions on peat bogs because of the presence not only of its larval host plants, but also of a favourable vegetation structure. This butterfly prefers low shrubs and trees where males perch for females and bask on the tops of branches (KRZYWICKI 1967, SHREEVE et al. 2009, THOMAS \& LEWINGTON 2010). The higher relative abundance of $C$. rubi at BM than at JG could be explained by the more numerous presence of its potential larval host plants (Vaccinium uliginosum and V. myrtillus) at the former site.

Little is known about the degree of association of both C. rubi and B. euphrosyne with peat bogs in Poland, as information about them is available only in reviews and general publications (e.g. SIELEZNIEW \& DZIEKAŃSKA 2010, BUSZKO \& MASŁOWSKI 2015). Specialist species are usually the main focus in faunistic papers (e.g. NOWACKI \& OSTAFIN 1989, NOWACKI 1992, FRĄCKIEL 1999) because of their high threat status (DĄBROWSKI \& KrzYWicki 1982, BuszKo \& NOWACKI 2002). Callophrys rubi is a common and widespread species (SIELEZNIEW \& DZIEKAŃSKA 2010, BusZKo \& MASŁOWSKI 2015) whereas B. euphrosyne is considered near-threatened nationally (BUSZKO \& NOWACKI 2002). The latter species occurs in two rather contrasting types of biotopes: apart from raised bogs, it is also observed in dry pine forests where its larvae feed on some Viola L. species. In the latter biotope, however, it is usually recorded in smaller numbers. The relationships between populations using different larval food plants are not known.

Interestingly KRZYwICKI (1967), who studied the butterflies of the Białowieża Primeval Forest and paid a fair amount of attention to peat bogs, did not observe B. euphrosyne in this kind of biotope at all, and assessed the occurrence of $C$. rubi there as merely temporary or accidental. He considered peat bogs to be the typical habitat only of $C$. palaeno, $P$. optilete, B. eunomia and B. aquilonaris. Only the last-mentioned species has not been recorded from the Knyszyn Forest (KLIMCZuK 2011). Studies of B. aquilonaris in Poland (OLEKSA 2003) and Belgium (Mousson et al. 1999) have shown that if a population of this species is to function properly, breeding habitats (rich in the larval host plant, i.e. Oxycoccus palustris) must adjoin open areas where nectar plants are available. 
The butterfly fauna of the Knyszyn Forest peat bogs that we have been studying is similar to that of the Notigale bog in northern Lithuania (DAPKUS 2010). However, the latter study was based only on three transect counts per season. The most frequently recorded butterfly was $C$. rubi, which DAPKUS (2001) considers to be only loosely associated with peat bogs. The second most numerous was $B$. euphrosyne (weak association with peat bogs). Boloria eunomia and C. palaeno were less abundant, and P. optilete was the least numerous. Interestingly, $P$. argus (LINNAEUs, 1758) was also abundant at the Lithuanian site, where it was classified as a tyrphophilous species, whereas in the Knyszyn Forest it is restricted to drier places.

Many factors affect the abundance of butterflies. In the current study we paid attention to the importance of canopy cover. Higher abundance indices were obtained for less dense patches than for those with denser tree cover. At BM the wide and light forest compartment line in the western part of the peat bog had a conspicuously positive influence on the abundance of all butterflies. Our observations are consistent with the results of NOREIKA et al. (2016), who demonstrated a significant negative correlation between the abundance of bog specialists (including B. eunomia, P. optilete and C. palaeno) and the number of taller trees (above $3 \mathrm{~m}$ ).

The two peat bogs and the populations of tyrphobionts inhabiting them seem to be very isolated. There are no data suggesting that they might be thriving in a metapopulation system or that there is an exchange of individuals between them or with any other populations. It is worth mentioning that BM and JG are the only known breeding sites of $C$. palaeno and $P$. optilete in the Knyszyn Forest. While B. eunomia has been recorded at a dozen or so sites, all those other populations (the nearest one is about $10 \mathrm{~km}$ away from JG and ca $20 \mathrm{~km}$ away from BM) belong to the second ecotype and inhabit wet meadows and fens (KLIMCZUK 2011 and unpublished). There is no evidence of any relationships between the two ecotypes of B. eunomia in the Knyszyn Forest.

The local status of tyrphophilous species is different, however. Both C. rubi and $B$. euphrosyne are known from many sites in the Knyszyn Forest (KLIMCZUK 2011) and they were recorded in the vicinity of our two raised bogs. One can assume, therefore, that the populations of these species at the study sites are not isolated.

It is hardly surprising that we obtained low Shannon-Wiener biodiversity indices (0.561.50) since we conducted our observations in highly homogeneous habitats. The values might have been a little higher if the butterfly counts had been made during the whole season (i.e. April-September). Higher values of this index, above 2.0, are achievable in studies of richer habitats and areas with diverse biotopes, even those subject to anthropogenic pressure (SIELEZNIEW 2001, SAARINEN et al. 2005). Indeed, in the case of large heterogeneous areas the index can reach values $>4.0$ (SETHY 2014). 
The relatively long flight period of $C$. rubi recorded in the present study is not surprising. In Finland it was calculated at 40.7 days, i.e. one of the longest of all butterfly species excluding these overwintering in the adult stage (KOMONEN et al. 2004). This phenomenon is probably closely related to the average life span, estimated at as long as 25 days (SETTELE et al. 2000). Interestingly, the flight periods of B. eunomia and $B$. euphrosyne in our study were distinctly shorter in each season than that of $C$. rubi. This is again consistent with the Finnish data, where the flight period of both Boloria species was calculated at 3-4 weeks (KOMONEN et al. 2004) and the estimates by SETTELE et al. (2000) suggesting that imagoes live for about two weeks. More reliable data based on MRR studies indicate that the average life span of B. eunomia and B. euphrosyne is even shorter - about 8-9 days (BUBOVÁ et al. 2016). Because of differences in life expectancy among butterfly species as well as appearance and behaviour influencing the detectability of individuals, transect counts are not a straightforward reflection of adult population sizes. This method gives estimates of relative abundance, so recorded numbers of particular species cannot be easily compared (POLLARD \& YATES 1995). For example, because of its longevity, numbers of $C$. rubi in comparison with Boloria species could have been relatively smaller in our study than those suggested by abundance indices.

The present study has demonstrated the importance of raised bogs as nectar resources not only for tyrphobionts and tyrphophiles but also for tyrphoneutral species, including migrants like Vanessa cardui (LinNAEUS, 1758). The majority of nectaring records refer to L. palustre, which appears to have been due to the abundance of this plant at both sites and the overlap of its flowering with the flight period of the most common butterflies associated with peat bogs. Moreover, the flowerheads of $L$. palustre are very conspicuous and exposed compared to other flowers present at the same time on peat bogs. Butterflies feeding on V. myrtillus, V. uliginosum and $O$. palustris are more difficult to spot, so the real use of these plant species could have been underestimated. It is possible that for the same reason we did not observe any butterfly visiting Andromeda polifolia, which is also mentioned as a nectar plant at peat bogs (DAPKUS 2001). Since our observations ended in late July, it was not possible to evaluate the significance of late flowering Calluna vulgaris, which was mentioned as a nectar source for V. cardui among other Lepidoptera on a peat bog in the Czech Republic (JAROŠ et al. 2014).

Our observations of ovipositing females of C. rubi and B. euphrosyne confirm that they can be classified as tyrphophiles. However, as far as the latter species is concerned it is not clear which plants are preferred. The literature mentions $V$. uliginosum as a larval host plant of B. euphrosyne on peat bogs (VÄISÄNEN 1992). In the Augustów Forest (situated north of the Knyszyn Forest) caterpillars of this butterfly were observed feeding on both $V$. uliginosum and $O$. palustris in spring (WARECKI 2010, M. SIELEZNIEW unpublished). 
In the case of B. eunomia, observations of oviposition as well as larval feeding are consistent and indicate that $O$. palustris is the only (or at least the main) food plant. These findings confirm the existence of the 'bog' ecotype of this species, existing independently of the 'meadow' ecotype, in the Knyszyn Forest. The potential role of played by other plants mentioned in the literature, i.e. V. uliginosum, and A. polifolia (VÄISÄNEN 1992, LENSU et al. 2011) remains unknown.

\section{CONCLUSIONS}

The present study has shown that, despite general patterns and trends, isolated islandlike habitats, such as peat bogs, may possess specific features and be subject to specific independent changes. The results also provided a good basis for further research into the habitat preferences of butterflies inhabiting these two raised bogs, which is particularly important in the context of endangered species. The only sporadic observations of Colias palaeno at both sites are alarming, as they suggest that the species may be threatened with local extinction. The occurrence of Plebejus optilete only at JG is also worrying, since it suggests that the butterfly may have already become extinct at BM. The dominance of generalists (including tyrphophilous species) over specialists at BM in comparison to JG is also worthy of notice. This may indicate that habitat conditions for the development of tyrphobionts are poorer at BM, but more detailed studies will be necessary to explain this.

New and extensive botanical research at both sites would certainly be helpful, in order to make meaningful comparisons with historical vegetation data (SOKOŁOWSKI 1985, 1986). The BM raised bog seems to be more susceptible to adverse changes than JG. The only phytosociological record repeated after 25 years indicates that, besides an increase in the number of plant species in the northern part of BM, the tree cover there is now denser (CZEREPKO 2011).

Basically, the two study sites are relatively well preserved raised bogs. They have not been drained or afforested, and natural succession seems to be the only threat. In the current situation, the recommended conservation action beneficial for tyrphobiontic species would be the removal of tall trees. Such a solution, including raising the water table level, has been successfully applied to the restoration of drained and afforested bogs in Finland (NOREIKA et al. 2016). Continuous monitoring of butterfly communities would be also vital for detecting long-term trends. 


\section{ACKNOWLEDGEMENTS}

Two anonymous reviewers made their comments on the manuscript.

\section{REFERENCES}

Bubová T., Kulma M., Vrabec V., Nowicki P. 2016. Adult longevity and its relationship with conservation status in European butterflies. Journal of Insect Conservation 20(6): 1021-1032.

BuszKo J. 1997. A distribution atlas of butterflies in Poland 1985-1995. Oficyna Wydawnicza Turpress, Toruń.

Buszko J. Nowacki J. 2002. Lepidoptera Butterflies. [in:] Z. GŁowAciński (ed.). Red list of threatened animals in Poland. Instytut Ochrony Przyrody PAN, Kraków, 80-87. (in Polish)

Buszko J. 2003. Poland. [in:] C.A.M. van SwaAy, M. Warren (eds.). Prime Butterfly Areas in Europe. Priority sites for conservation. Ministry of Agriculture, Nature Management and Fisheries, The Netherlands, 399-401.

Buszko J., MasŁowski J. 2015. Butterflies of Poland. Wydawnictwo „Koliber”, Nowy Sącz. (in Polish)

CZEREPKo J. 2008. A long-term study of successional dynamics in the forest wetlands. Forest Ecology and Management 255(3-4): 630-642.

CZEREPKO J. 2011. Long-term vegetation change in marshy pine forest Vaccinio uliginosi-Pinetum KLEIST 1929. Leśne Prace Badawcze 72(1): 21-29. (in Polish)

DAPKUS D. 2001. Macrolepidoptera of Lithuanian peatbogs. Norwegian Journal of Entomology 48(1): 161-166.

DAPKUS D. 2010. Check-list of butterflies and moths of the Notigale bog (Northern Lithuania). New and Rare for Lithuania Insect Species 22: 91-100.

DĄBrowski J.S., KRZYwicki M. 1982. Extinct and endangered species of Lepidoptera of Polish fauna. Studia Naturae ser. B 31: 1-171. (in Polish)

FrĄCKIEL K. 1999. Butterflies (Lepidoptera: Papilionoidea, Hesperioidea) of the Biebrza National Park. Wiadomości Entomologiczne 18(2): 85-98. (in Polish)

JAROŠ J., SPITZER K., ZiKMUNDOWÁ H. 2014. Variability of Lepidoptera communities (moths and butterflies) along an altitudinal gradient of peat bogs from the Třeboň Basin up to the Bohemian Forest (South Bohemia, Central Europe). Silva Gabreta 20(2): 55-95.

Klimczuk P., Twerd J. 2000. Butterflies (Papilionoidea and Hesperioidea) in the Knyszyńska Forest as well as in the environs of Białystok. Parki Narodowe i Rezerwaty Przyrody 19(3): 85-97. (in Polish)

KLIMCZuK P. 2011. Butterflies (Hesperioidea, Papilionoidea) of the Knyszyn Forest (Puszcza Knyszyńska) and adjacent woodland areas of Białystok - in the years 1995-2010. Nature Journal 44: 197-217. 
Komonen A., Grapputo A., Kaitala V., Kotiaho J.S., PÄıvinen J. 2004. The role of niche breadth, resource availability and range position on the life history of butterflies. Oikos 105(1): 41-54.

KrZYsZtofiak L., KrZYSZTOFIAK A., RomańSKi M. 2009. Biology and ecology of the Jutta Arctic Oeneis jutta (HÜBNER, 1806) (Lepidoptera: Nymphalidae). Polish Journal of Entomology 78(3): 265-275.

KrZYwiCKI M. 1967. Papilionoidea und Hesperioidea (Lepidoptera) des Białowieżaer Urwalds. Annales zoologici 25(1): 1-215. (in Polish)

Kudrna O., Harpke A., Lux K., Pennerstorfer J., Schweiger O., Settele J., Wiemers M. 2011. Distribution atlas of butterflies in Europe. Gesellschaft für Schmetterlingsschutz, Halle.

Lensu T., Komonen A., Hiltula O., PÄIVinen J., SAARi V., Kotiaho J.S. 2011. The role of power line rights-of-way as an alternative habitat for declined mire butterflies. Journal of Environmental Management 92(1): 2539-2546.

MiKkola K., SPITZER K. 1983. Lepidoptera associated with peatlands in central and northern Europe: a synthesis. Nota lepidopterologica 6(4) 216-229.

Minayeva, T. 2008. Chapter 5: Peatlands and biodiversity. [in:] F. PARISH, A. SiRIN, D. Charman, H. Joosten, T. Minayeva, M. Silvius, L. Stringer (eds.). Assessment on Peatlands, Biodiversity and Climate Change: Main Report. Global Environment Centre, Kuala Lumpur and Wetlands International, Wageningen, 60-98.

Mousson L., NÈve G., Baguette M. 1999. Metapopulation structure and conservation of the cranberry fritillary Boloria aquilonaris (Lepidoptera, Nymphalidae) in Belgium. Biological Conservation 87(3): 285-293.

Noreika N., Kotze D.J., Loukola O.J., Sormunen N., Vuori A., PÄivinen J., Penttinen J., Punttila P., Kotiaho J.S. 2016. Specialist butterflies benefit most from the ecological restoration of mires. Biological Conservation 196: 103-114.

Nowacki J., Ostafin T. 1989. The interesting species of Lepidoptera from peat bog within the Roztoczański National Park. Parki Narodowe i Rezerwaty Przyrody 9(1): 21-25. (in Polish)

NowACKI J. 1992. The butterflies of the Roztocze National Park (Lepidoptera). Wiadomości Entomologiczne 11(4): 221-227. (in Polish)

OLEKSA A. 2003. Environmental requirements and structure of metapopulation of the Cranberry Fritillary Boloria aquilonaris STICHEL, 1908 in the Iławskie and Olsztyńskie Lake Districts. Ph.D. thesis, Nicolaus Copernicus University, Torun. (in Polish)

Sethy J., Behera S., Chauhan N.S. 2014. Species diversity of Butterflies in South-Eastern part of Namdapha Tiger Reserve, Arunachal Pradesh, India. Asian Journal of Conservation Biology 3(1): $75-82$.

Settele J., Feldmann R., Reinhardt R. 1999. Die Tagfalter Deutschlands. Ulmer, Stuttgart.

SIELEZNIEW M. 2015. Marsh Fritillary Euphydryas aurinia in Knyszyn Forest. Chrońmy Przyrodę Ojczystą 71(3): 221-228. (in Polish)

SieleZniew M., DZIEKAŃska I. 2010. Fauna of Poland. Butterflies. MULTICO Oficyna Wydawnicza, Warszawa. (in Polish) 
SielezNiEw M., Nowicki P. 2017. Adult demography of an isolated population of the threatened butterfly Scarce Heath Coenonympha hero and its conservation implications. Journal of Insect Conservation 21(4): 737-742.

SoKoŁowsKi A.W. 1985. Vegetation of the reserve Jesionowe Góry in Knyszyńska Forest. Parki Narodowe i Rezerwaty Przyrody 1(6): 11-32. (in Polish)

SokoŁowski A.W. 1986. Vegetation of the "Lazarz" Reserve in Knyszyn Forest. Parki Narodowe i Rezerwaty Przyrody 1(7): 35-38. (in Polish)

SPITZER K., DANKS H. V. 2006. Insect biodiversity of boreal peat bogs. Annual Review of Entomology 51: 137-161.

ShreEve T., KonvičKa M., VAN Dyck H. 2009. Functional significance of butterfly wing morphology variation. [in:] J. SETTELE, T. Shreeve, M. KonviČKA, H. VAN DycK (eds.). Ecology of Butterflies in Europe. Cambridge University Press, Cambridge, 171-188.

SWAAY C.A.M. van, WARREN M.S. 1999. Red Data Book of European Butterflies (Rhopalocera). Nature and Environment, No. 99, Council of Europe Publishing, Strasbourg.

SwaAy C.A.M. van, CutTelod A., Collins S., Maes D., López Munguira M., Šašić M., SetTele J., Verovinik R., Verstrael T., Warren M., Wiemers M., Wynhoff I. 2010. European Red List of Butterflies. European Union, Luxembourg.

Swengel A.B., Swengel S.R. 2011. High and dry or sunk and dunked: lessons for tallgrass prairies from quaking bogs. Journal of Insect Conservation 15(1-2): 165-178.

Thomas J., Lewington R. 2010. The butterflies of Britain \& Ireland. British Wildlife Publishing, Gillingham, Dorset.

Uusitalo A., Kotiaho J., Päivinen J., Rintala T., SaARi V. 2012. Species richness and abundance of butterflies in natural and drained mires in Finland. [in:] T. LindhOLM, R. HeikKILÄ (eds.). Mires from pole to pole. The Finnish Environment (38). Finnish Environment Institute, Helsinki, 205-214.

VÄISÄNEN R. 1992. Distribution and abundance of diurnal Lepidoptera on a raised bog in southern Finland. Annales Zoologici Fennici. 29(2): 75-92.

Vasander H., Tuittila E.S., Lode E., Lundin L., Ilomets M., Sallantaus T., Heikkilä R., PITKÄNEN M.L., LAINE J. 2003. Status and restoration of peatlands in northern Europe. Wetlands Ecology and Management 11(1-2): 51-63.

WARECKI A. 2010. Butterflies of Poland. Atlas od bionomy. Koliber, Nowy Sącz. (in Polish)

Received: 7 April 2017

Accepted: 13 June 2017 